\title{
Morphological, ecological and molecular characterization of Pyropia vietnamensis (Bangiales, Rhodophyta) from the Konkan region, India
}

\author{
MONICA G. KAVALE ${ }^{1 *}$, MUDASSAR ANISODDIN KAZI', NIVED SREENADHAN ${ }^{1}$ \& VEERENDRA V. \\ $\mathrm{SINGH}^{2}$ \\ 'Department of Botany, I. C. S. College, Khed, Ratnagiri, Maharashtra, 415 709, India \\ ${ }^{2}$ ICAR-Mumbai Research Centre of Central Marine Fisheries Research Institute, Mumbai 400061, India \\ Corresponding author: *monicakavale@gmail.com
}

\begin{abstract}
Pyropia vietnamensis is one of the most luxuriously growing seaweed in Konkan coast, India. In the present study we attempted to explore the morphology, ecology and molecular characteristics exhibited by $P$. vietnamensis and its taxonomic implications. We described the effects of ecological parameters on the variability of morphological characters. The water motion was found to be one of the most important ecological parameter that governs the plant morphology. The plant was found to grow on entire intertidal region and this may be one of the possible reasons for high morphological variation among the taxa in this region. The molecular analysis utilizing $\operatorname{cox} 1$ gene sequences clearly revealed the close relation of Indian and Brazilian specimens with only $0-1$ bp intraspecific variation. The present study provides a beginning to a clearly required detailed study of the morphology, ecology and genetic diversity showed by Pyropia species from Indian waters.
\end{abstract}

Key words: Pyropia, morphological plasticity, morphometrics, coxl, phylogenetic analysis, taxonomy

\section{Introduction}

The marine macroalga Pyropia vietnamensis (Tak. Tanaka \& P.H. Ho) J.E. Sutherland \& Monotilla was first described from the upper littoral zone of Vung-Tau (Cap. St. Jacqus), Vietnam by Tanaka \& Ho (1962). The taxon was distinguished from its closest relative Pyropia denticulate Levring based on its difference in frond size and the division formula of spermatia. $P$. vietnamensis is one of the most important and abundantly growing seaweed in India (Sahoo et al. 2001). Its occurrence was first reported by Sreeramulu (1952) as Porphyra naiadam Anderson from Waltair, Visakhapatnam, India during the summer season (February to June) and later on same specimen was identified as $P$. vietnamensis by Umamaheswara Rao \& Sreeramulu (1963). P. vietnamensis was also reported from Dona Paula, Goa (Dhargalkar et al. 1981) and Colaba Coast, Maharashtra (Deodhar 1985) in monsoon season during the months of June to September. Both Dona Paula and Colaba Coast falls within the Konkan region situated along the West coast of India.

Konkan is a northern part of the western coastal plain of India, situated between the Western Ghats and the Arabian Sea. It is a narrow strip of about $50 \mathrm{~km}$ width that stretches from $15^{\circ} 37^{\prime}$ to $20^{\circ} 20^{\prime}$ latitude and $70^{\circ} 07^{\prime}$ to $74^{\circ} 13^{\prime}$ ' longitude. The Konkan coast is characterized by numerous backwaters, lagoons and rocky cliffs. However, from the above reports it is clear that very few attempts have been made to explore the diversity of $P$. vietnamensis from this region. It was surprising to note that, the world's highly important and commercialized algal genus remained underutilized by phycologist; despite its abundance on the Konkan coast.

We realized the possible reasons for such apparent apathy during the collection of Pyropia. It is amply clear from our survey that the occurrence of the alga was visible during monsoon season (June-September). During this period, the coast experienced very heavy rain, coupled with strong and huge waves hitting the coast. Consequently, the fishing activities in this region also cease. These prevailing odd environmental conditions might have been deterrent for phycologists to plan and execute collections of Pyropia during the monsoon period.

Recently, biodiversity assessment study of economically important seaweeds was undertaken by authors along the west coast of India. We observed two different species of Pyropia along the Konkan region. Among these two species, one was identified as $P$. acanthophora, a new report from the Indian region and subsequently reported as a 
new variety $P$. acanthophora var. robusta (Kavale et al. 2014). The second species was $P$. vietnamensis. We found notable morphological variations in $P$. vietnamensis. Although, several publications have appeared with respect to its developmental, chemical and ecological studies(Anilkumar et al. 2005, Sahoo et al. 2006, Subbarao et al. 2007, Bhatia et al. 2010, Kavale et al. 2013, Kumari et al. 2013); least attention was paid towards its systematics from the Konkan coast. Thus, the present study mainly focuses on morphological, ecological and molecular characterization and their taxonomical implication to understand the variation patterns in $P$. vietnamensis.

\section{Material \&Methods}

\section{Collection}

The specimens analysed were collected from several locations along the coastal plain of the Konkan region. The sites selected for collection are shown in Supplementary File, Fig. S1. Collection was made during the monsoon season (July-September). Principle of random sampling was followed during the collections. The plants were found growing on rocks in the supralittoral and eulittoral zones. The specimen was handpicked. The colour of the alga and the extent of their growth were recorded in the field itself. Geomorphology and ordinates of collection sites are given in Supplementary File, Table S1. Specimens were washed two to three times with sea water to remove adhering materials such as sand particles, other debris as well as epiphytes. A solution of $4 \%$ formalin in seawater was used as preservative. The collected material was preserved for further processing and characterization. Herbariums of the specimens were made and submitted to the repository of Central National Herbarium, Botanical Survey of India, Kolkata, India. Fresh specimens were stored at $-20^{\circ} \mathrm{C}$ for the isolation of genomic DNA.

\section{Morphological characterization}

Initially specimens were assorted based on their shape and texture. Minimum 30 thalli of each specimen type were used for observations. Length and width of the thalli were measured using thread and scale. Free hand sections were taken for characterization. The features selected for the morphological characterization were shape, size, texture and colour of the plant, base of the blade, nature of margins, thickness of the thallus, thickness of the mucilage, diameter of monospores, diameter of vegetative and reproductive cells, distribution, division formula and number of fertile cells etc. $1 \%$ aqueous Toludine Blue and $1 \%$ aqueous saffranine were used for staining and was mounted in a medium containing $50 \%$ glycerin. Micrometer and ocular scales were used to determine the dimensions of the material. Morphological observations were carried out on compound and phase contrast microscope (Motic, Hong Kong). The characteristics of specimens were compared with previously published reports for identification (Tanaka \& Ho 1962, Krishnamurthy \& Baluswami 1984).

\section{Morphometric analysis}

The morphological characters representing shape and size of the plant, habitat, nature of margin, color of the plant, occurrence of spines, thickness of mucilage and thickness of the thallus in reproductive and vegetative part were scored for the morphometric studies. Minimum 30 observations were taken for each character. The cluster analysis was performed by UPGMA (unweighted pair group method with arithmetic mean algorithm) in Multi-Variate Statistical Package (MVSP) program (Everitt, 1980).

\section{Molecular characterization}

Total DNA was extracted with the Gene Elute ${ }^{\mathrm{TM}}$ Plant Genomic DNA miniprep kit (Sigma Aldrich, St. Louis, USA) following the manufacturer's protocol. Amplification by PCR was performed in a master mix of volume $25 \mu \mathrm{l}$ containing $200 \mu \mathrm{M}$ of each dNTP, $5 \mathrm{pmol}$ of each primer, $1 \mathrm{X}$ assay buffer, and 1.25 units of Taq DNA polymerase. The cox 1 (cytochrome $c$ oxidase subunit 1) gene was amplified using primers GazF1: 5'- TCAACAAATCATAAAGATATTGG - 3' and GazR1: 5'- ACTTCTGGATGTCCAAAAAAYCA - 3' (Saunders 2005). The amplification profile for coxl followed Saunders (2005). The PCR products were purified with a Gene Elute ${ }^{\mathrm{TM}}$ Gel Extraction Kit (Sigma Aldrich, St. Louis, USA) and sent for commercial sequencing (Xcelris Labs Ltd., India). The sequences were deposited in GenBank under the accession numbers shown in Supplementary File, Table S1.

The phylogenetic analysis of coxl gene data was carried out in MEGA version 6 (Tamura et al. 2013). The maximum likelihood (ML) tree was constructed using General Time Reversible (GTR) (Tavaré 1986) nucleotide substitution model with discrete Gamma distribution $(+\mathrm{G})$ and invariant sites $(+\mathrm{I})$. Best suited evolutionary model was estimated in 
MEGA version 6 under the Bayesian Information Criterion (BIC) (Schwarz 1978). Support for branches was estimated by 1000 bootstrap replicates (Felsenstein 1985). The pairwise distances between sequences were calculated using the Kimura two parameter (K2P) distance model (Kimura 1980) in MEGA version 6.

\section{Results}

The data presented in this study is the outcome of the algal collection made from August 2012 to September 2013 from various locations along the Konkan coast. Of the 22 sites visited, P. vietnamensis was found growing only at 12 locations as listed in Table S1. A total of 15 specimens were studied for their ecological, morphological and molecular characteristics.

\section{Ecological characterization}

It was observed that the growth of $P$. vietnamensis starts in the month of June. By the first half of August a fully grown thalli was observed i. e. the vegetative thalli appeared during the month of July and developed to its reproductive stage by first week of August. The growth of alga started declining with the end of monsoon and vanished by the end of September. The plants were found to be growing on different kinds of rocky substrate (Supplementary File, Table S1). It grows in patches towards the low water mark and then gradually spreads and covers the entire rock surface up to high tide water mark. The other species like Ulva, Ceramium, Chaetomorpha, Spongomorpha and Sphacelaria were also observed as associates of $P$. vietnamensis. However, at the end of monsoon season other species like Ulva and Grateloupia started encroaching over $P$. vietnamensis.

\section{Morphological characterization}

Morphological characters of $P$. vietnamensis specimens are enlisted in Supplementary File, Table S2. The plants are 4-30 cm in height and 1.5-15 cm in width (Figs. 1-15). At younger stage plants look greenish brown and at maturity it turns brownish red. The plants turned purple brown, purple pink and brown after drying. The plants vary in shapes as linear, orbicular, lanceolate, orbilanceolate, ovate pyramidal and irregular (Figs. 1-15). Blades were sessile with cordate base and delicate in texture. Several blades arise from a discoid holdfast. Margin of the blades were plain to undulate with ruffled surface and with numerous spines (Figs. 1-15, Figs. 16-30). The spines were 1-2 celled and up to $9.9 \mu \mathrm{m}$ in height (Figs. 16-30). The plants in eulittoral zone showed higher number of spines as compared to supralittoral zones. Generally the spines were observed in the lower to middle region of the blade. The thalli were monostromatic, $23.1-49.5 \mu \mathrm{m}$ thick in vegetative part (Figs. 31-45) and 29.7-52.8 $\mu \mathrm{m}$ in reproductive part (Figs. 46 75). The vegetative cells were found to be polygonal with blunt corners and ranged from 13.2-23.1 $\mu \mathrm{m}$ in its greatest dimensions. In cross section vegetative cells were one to two times higher than broader and ranged from 16.5-26.4 $\mu \mathrm{m}$ in height and 6.6-16.5 $\mu \mathrm{m}$ in width. The shape of the vegetative cells in the cross section was rectangular with rounded corners. The surface mucilage was 6.6-13.2 $\mu \mathrm{m}$ thick on the either side of the section. Each vegetative cell consisted of a stellate chloroplast with a central pyrenoid. The monosporangia were produced on the marginal region. The monospores were round with diameter up to $23.1 \mu \mathrm{m}$. The plants were monoecious. Mostly spermatangia and zygotosporangia were observed in mixed form and occasionally as irregular patches or in strips (Figs. 76-78). The spermatangia and zygotosporangia were easily differentiated by their color. The spermatangia were colorless to pale yellow while zygotosporangia appeared reddish brown in colour. There were 64 spermatia in each spermatangium with division formula as $\mathrm{a} / 4, \mathrm{~b} / 4, \mathrm{c} / 4$ and measured upto $3.3 \mu \mathrm{m}$ in diameter. Each zygotosporangium consisted of 8 zygotospores ranging from $6.6-13.2 \mu \mathrm{m}$ in diameter and their division formula as $\mathrm{a} / 2, \mathrm{~b} / 2, \mathrm{c} / 2$.

\section{Morphometric analysis}

The phenogram (Fig. 79) showed two main clusters, Cluster I and Cluster II. Cluster I included specimens Dona Paula, Redi, Palshet, Hedavi I, Harihareshwar, Malvan I and Shekhadi. Cluster II included specimens Anjuna, Vagathor, Purnagad I, Velaneshwar, Hedavi II, Malvan II, Purnagad II and Kolthare. These two clusters were mainly separated based on their size and shape of the plant; wave exposed and wave sheltered habitat. Cluster I included specimen which grows on wave shelter area while Cluster 2 comprised of specimens that grows on wave exposed area except Purnagad I and Kolthare. The plants which were directly exposed to waves showed characteristically narrow width and longer length. The shape of these plants varied between linear to lanceolate and margin was plain with ruffled surface. On the other hand the specimens which were growing in semi-sheltered region showed variation in shapes 

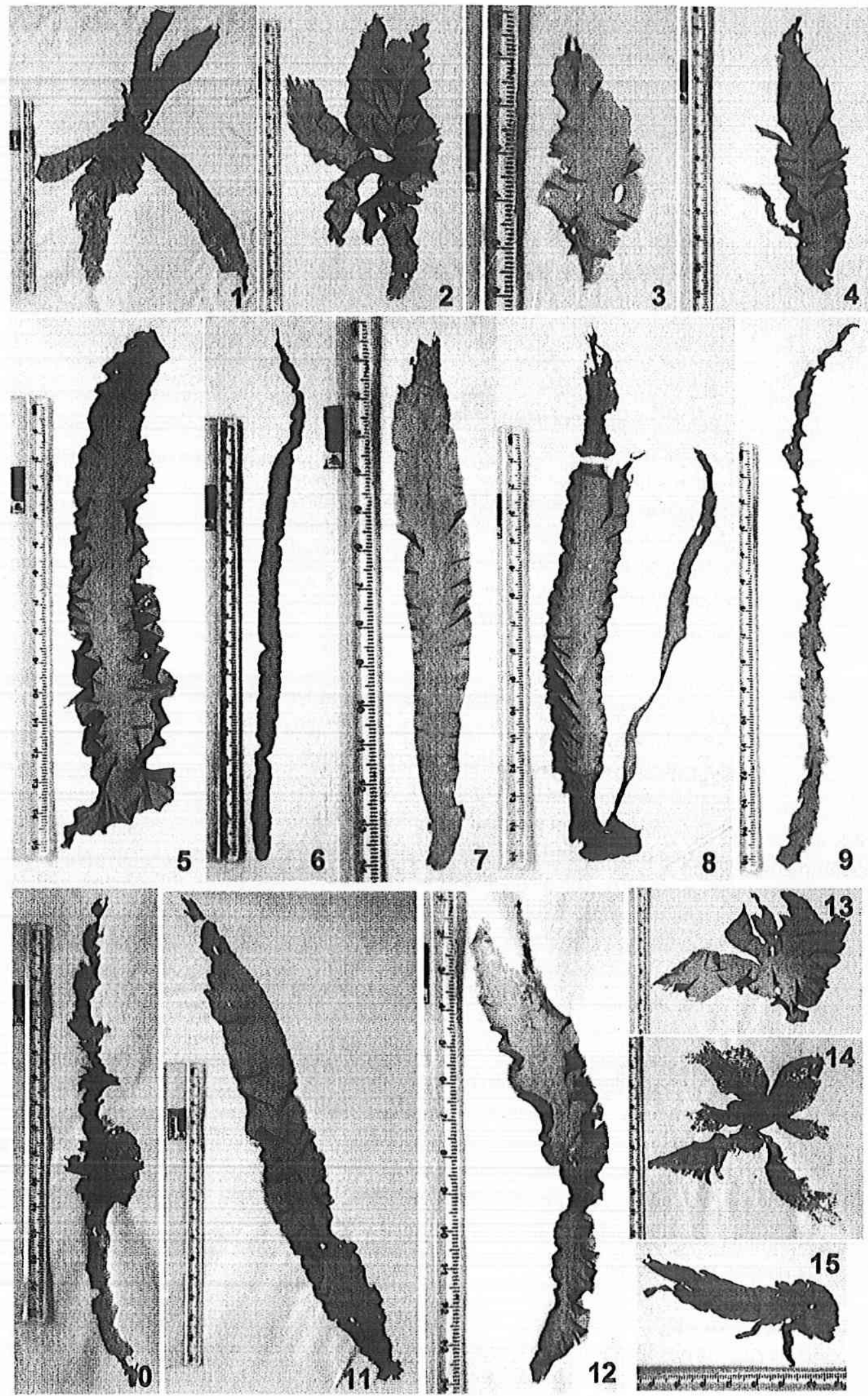

FIGURES 1-15. Habit of Pyropia vietnamensis. 1. Harihareshwar (ARC- P- 31). 2. Shekhadi (ARC- P- 80). 3. Kolthare (ARC- P- 23). 4. Palshet (ARC- P- 3). 5. Malvan (ARC- P- 48). 6. Malvan (ARC- P- 69). 7. Purnagad (ARC- P- 21). 8. Purnagad (ARC- P-22). 9. Velaneshwar (ARC- P- 8). 10. Anjuna (ARC- P- 192). 11. Hedavi (ARC- P- 12). 12. Vagathor (ARC- P- 196). 13. Hedavi (ARC- P- 20). 14. Dona Paula (ARC- P- 183). 15. Redi (ARC- P- 73). 


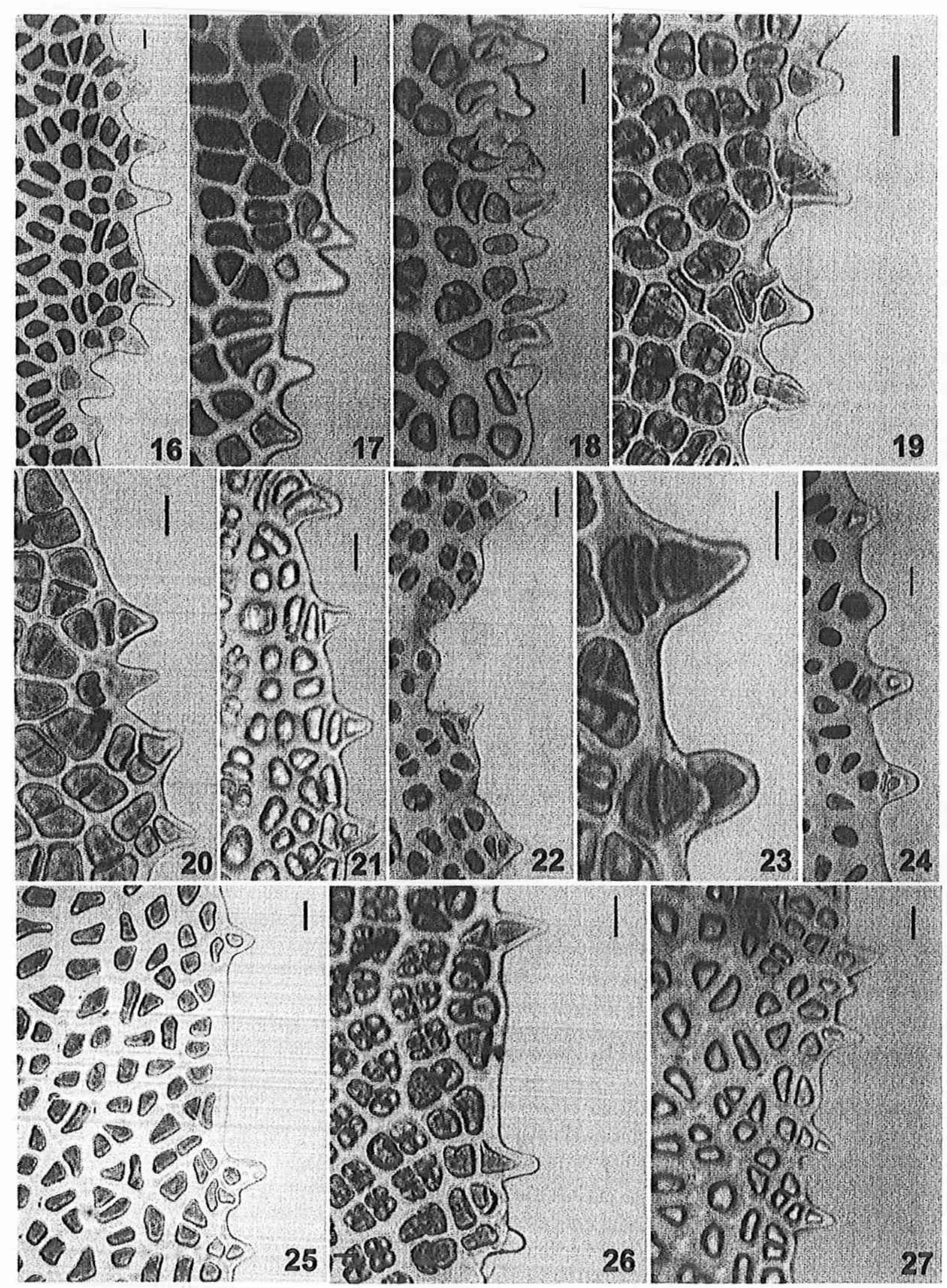

FIGURES 16-27. Spinulose margin of thallus. Scale bar $=10 \mu \mathrm{m}$. 16. Anjuna. 17. Vagathor. 18. Malvan II. 29. Velaneshwar. 20. Hedavi II. 21. Purnagad I. 22. Redi. 23. Hedavi I. 24. Malvan I. 25. Dona Paula. 26. Palshet 27. Purnagad II 


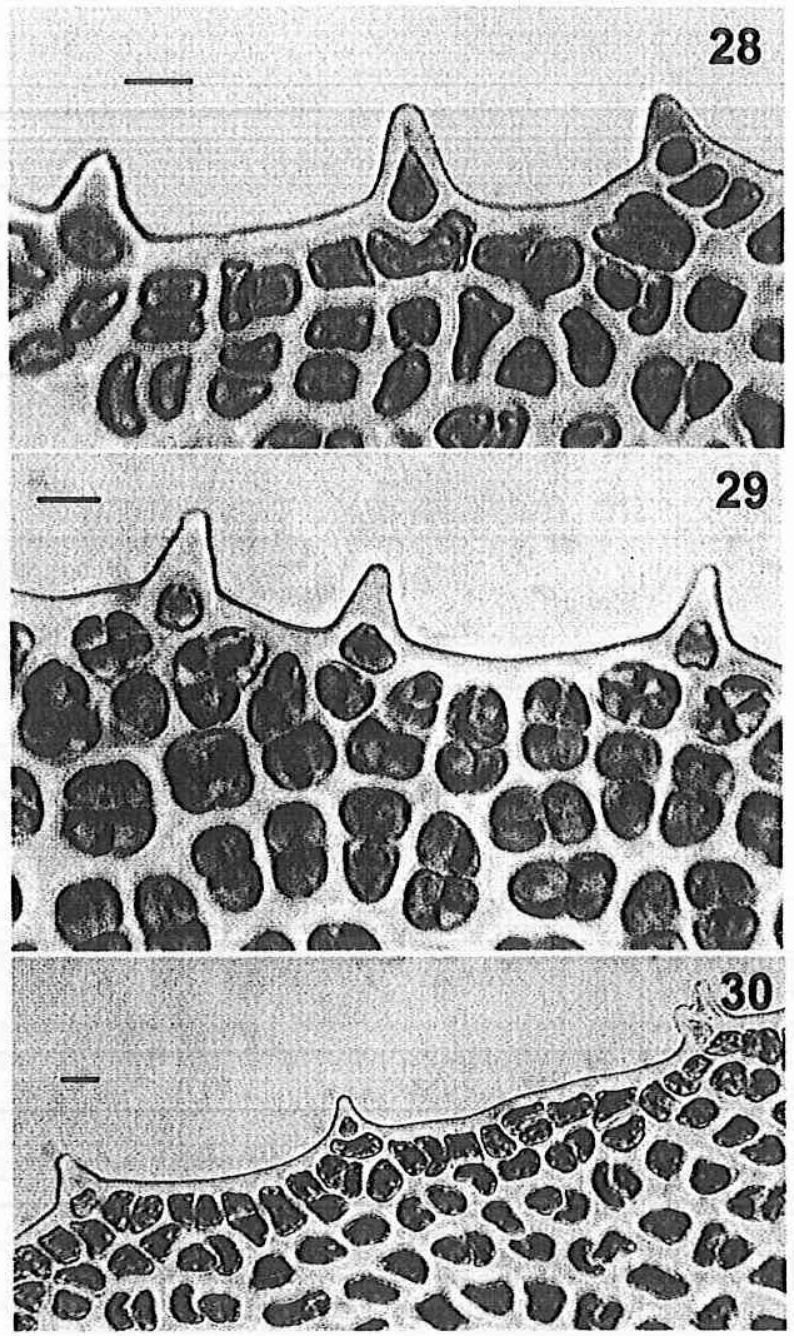

FIGURES 28-30. Spinulose margin of thallus. Scale bar $=10 \mu \mathrm{m}$. 28. Kolthare. 29. Harihareshwar. 30. Shekhadi.

as lanceolate, oblanceolate, ovate and orbicular and occasionally irregular and less ruffled margin except Shekhadi. However, specimen Purnagad I was linear to lanceolate in shape despite its occurrence in semi-sheltered region. Cluster I was subdivided into two sub-clusters I and II based on thickness of thallus in vegetative and reproductive area, thickness of the mucilage and ruffled surface. Cluster II was differentiated into two sub-clusters viz. sub-cluster III and IV. In sub-cluster III, specimens Hedavi II, Velaneshwar and Purnagad were clustered together and showed very high similarity. These specimens were separated from Vagathor and Anjuna specimens on the basis of color of alga after drying. Specimens Hedavi II, Velaneshwar and Purnagad I were purple brown in color while specimens Anjuna and Vagathor showed brown color. The Malvan II formed a separate lineage from rest of the specimens in the Sub-cluster III due to the plant width and color of the alga after drying. The width of Malvan II was very less (up to $1 \mathrm{~cm}$ ) as compared with rest of the specimens. The sub-cluster IV consisted of specimens Purnagad I and Kolthare. Both specimens were separated from sub-cluster III by less ruffled surface and occurrence of spines.

\section{Molecular characterization}

A total of 43 sequences of $\operatorname{cox} 1$ gene were used to generate the dataset consisting of 672 nucleotide positions in total alignment length. The dataset included 227 parsimony informative, 427 conserved and 245 variable sites. All Indian specimens of $P$. vietnamensis showed monophyletic association in present ML tree (Fig. 80) with bootstrap support of $100 \%$. P. vietnamensis (JN222751) reported from Pedra do Sal, Parnaiba, Brazil by Milstein et al. (2010) grouped in same clade. However, P. vietnamensis (HQ422669) of Hawaiian origin (Sherwood et al. 2010) was recovered as sister lineage with strong bootstrap support of $87 \%$. Specimens ARC-P-31 and ARC-P-23 diverged by single synonymous nucleotide substitution from other $P$. vietnamensis sequences making maximum intraspecific genetic distance upto 
$0.2 \%$. However, the sequence variation of Hawaiian specimen of $P$. vietnamensis ranged from $10.1 \%$ to $10.3 \%$ with other specimens. In phylogenetic tree this Hawaiian specimens showed close association with $P$. acanthophora. The genetic distance between Hawaiian specimen and $P$. acanthophora clade was observed to be $5.7 \%$.

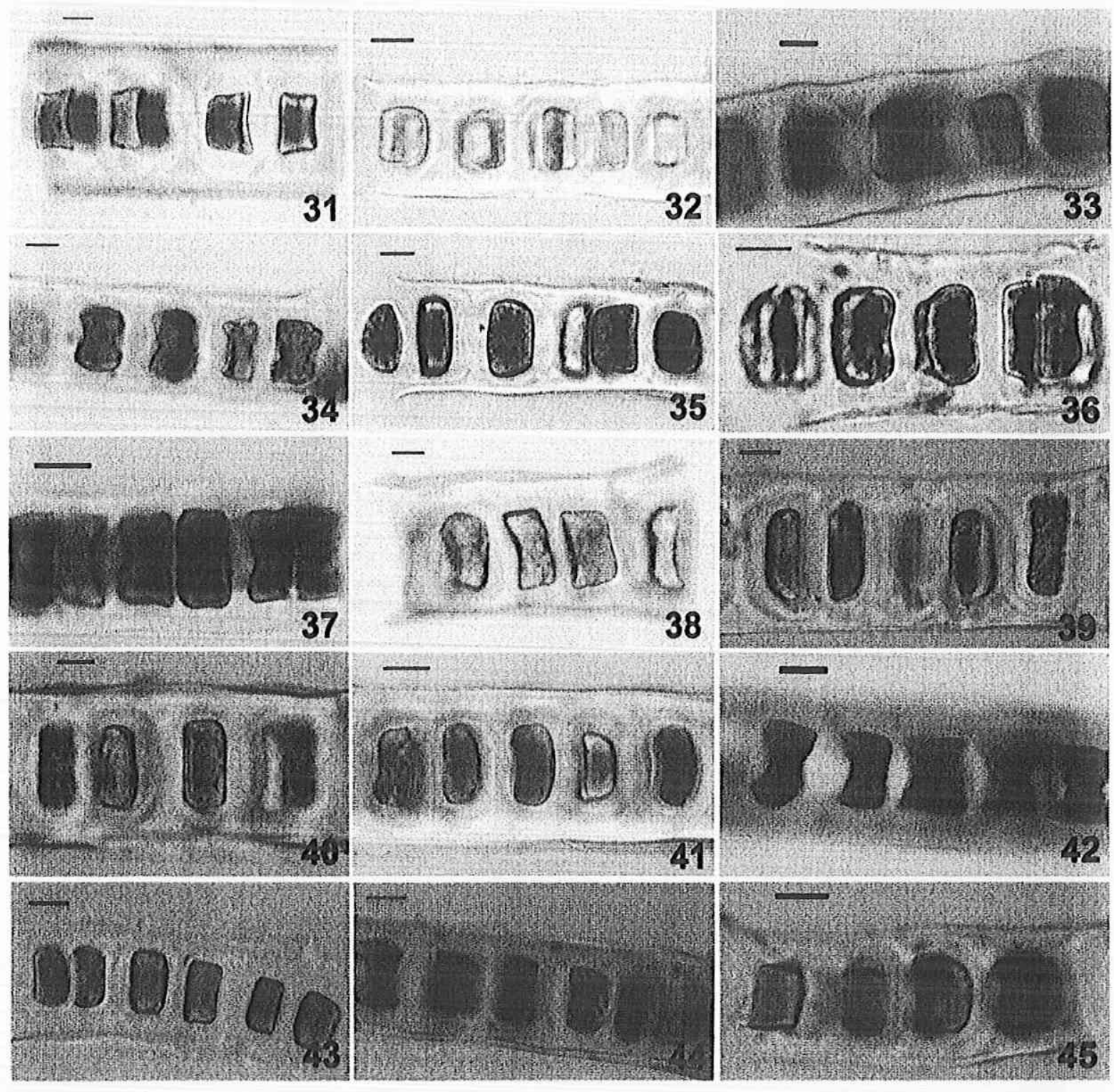

FIGURES 31-45. Cross section of blade passing through vegetative area. Scale bar $=10 \mu \mathrm{m} .31$. Redi. 32. Hedavi 1. 33. Kolthare. 34 . Vagathor. 35. Purnagad II. 36. Harihareshwar. 37. Dona Paula. 38. Hedavi II. 39. Malvan II. 40. Velaneshwar. 41. Anjuna. 42. Malvan I. 43. Palshet. 44. Purnagad I. 45. Shekhadi.

\section{Discussion}

\section{Ecological characterization}

It was observed that in Konkan coast the life cycle of $P$. vietnamensis completely depends upon the intensity of monsoon. During monsoon, atmosphere remains cloudy with high levels of humidity (up to 100\%) and temperature gradually decreases as compared to summer. The salinity of sea water also decreases. All these parameters appeared to favor the growth of $P$. vietnamensis. This observation corroborated with Pereira et al. (2005). Plant growth was mainly governed by factors such as substratum, tide, water motion, availability of nutrients, light, temperature, salinity, competition (Lobban et al. 1985, Grahan \& Wilcox 2000). In the present study, water motion was found to be one of the most important factors that govern the plant morphology. The plants which were exposed to wave action showed 

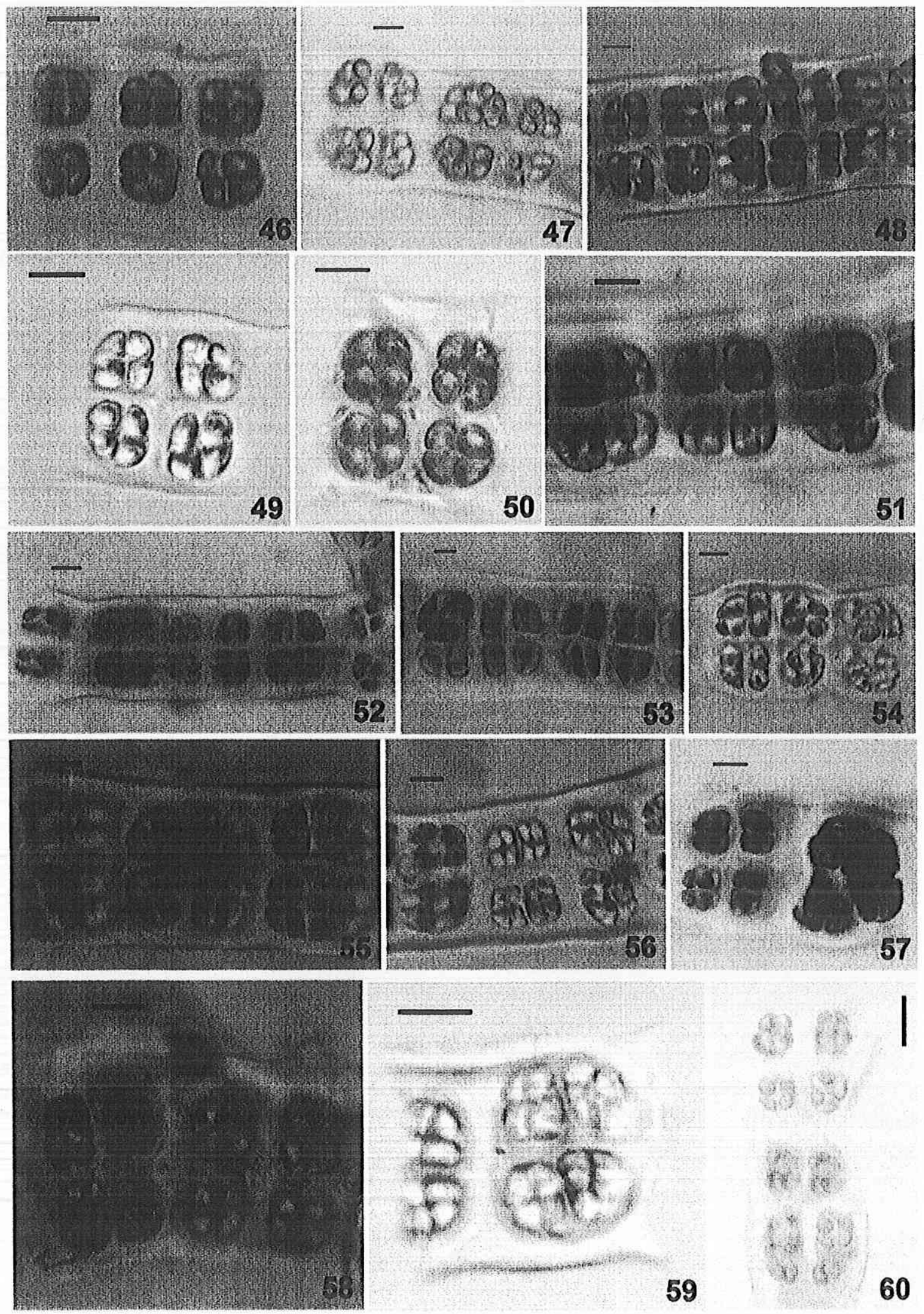

59
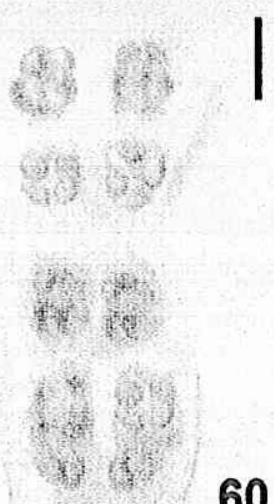

60

FIGURES 46-60. Cross section of blade passing through Spermatangia. Scale bar $=10 \mu \mathrm{m}$. 46. Redi. 47. Harihareshwar. 48. Palshet 49. Dona Paula. 50. Hedavi I. 51. Vagathor. 52. Kolthare. 53. Anjuna. 54. Malvan I. 55. Purnagad I. 56. Hedavi II. 57. Malvan II. 58.Shekhadi. 59. Velaneshwar. 60. Purnagad II. 

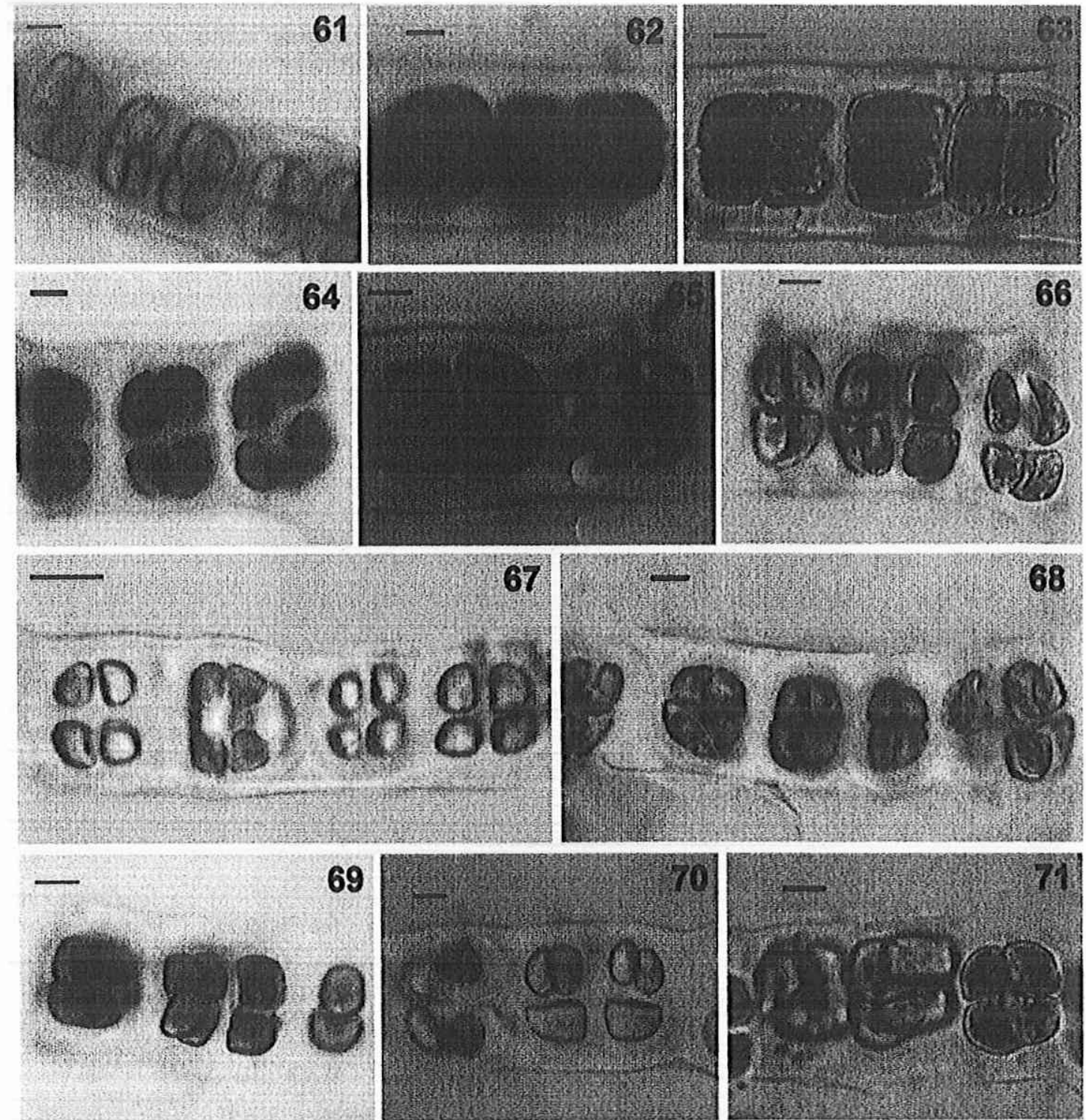

68
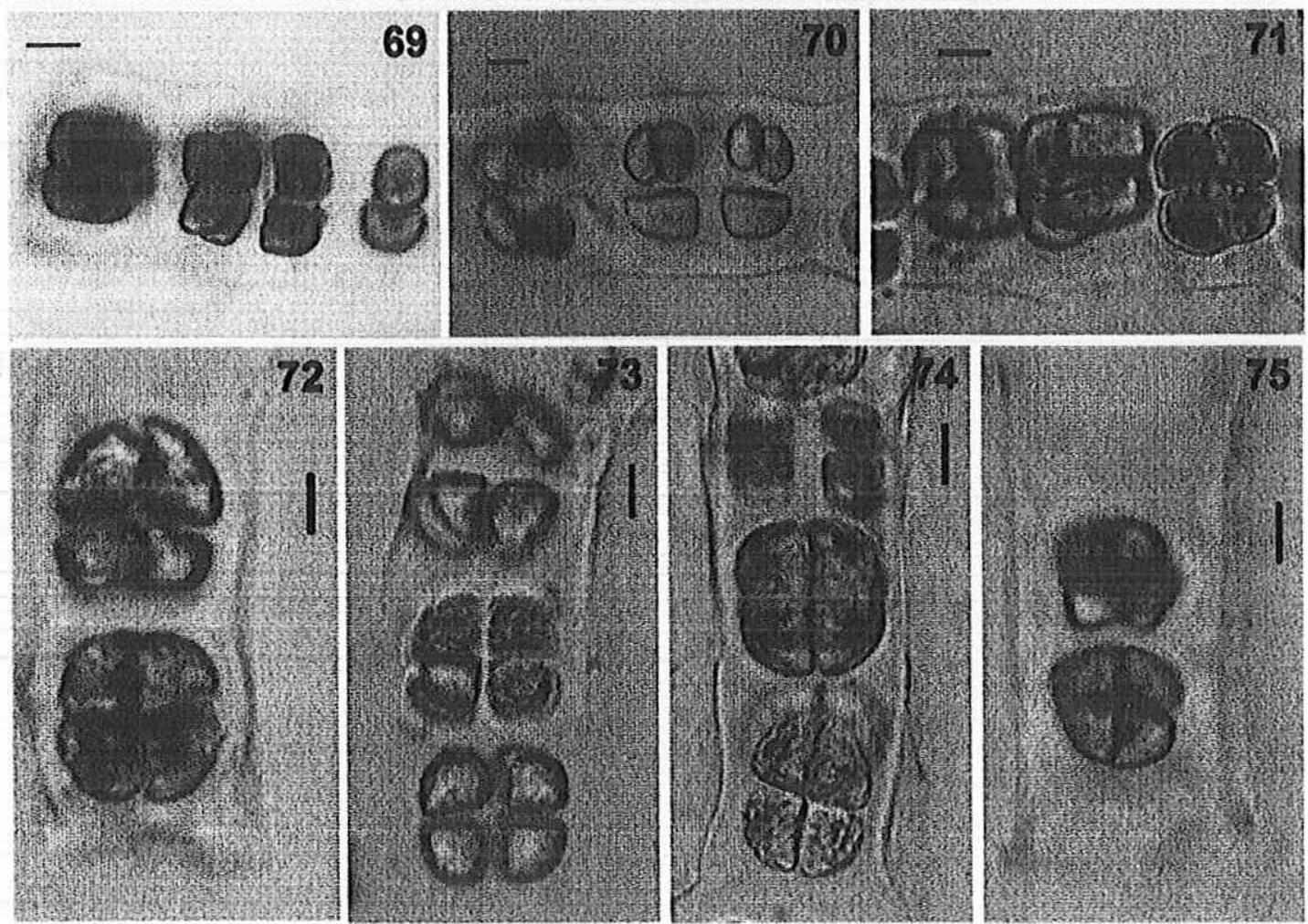

FIGURES 61-75. Cross section of blade passing through zygotosporangia. Scale bar $=10 \mu \mathrm{m} .61$. Palshet. 62. Vagathor. 63. Dona Paula. 64. Hedavi I. 65. Redi 66. Kolthare. 67. Purnagad II. 68. Malvan II. 69. Hedavi II. 70. Shekhadi. 71. Harihareshwar. 72. Malvan I. 73. Velaneshwar. 74. Anjuna. 75. Purnagad I. 
maximum spines and ruffled margin. This may be an adaptation for survival so as to reduce the damaging effect of the dragging force. Lobban \& Harrison (1994) found that in sheltered intertidal region spines stimulate nutrient uptake. It was also observed that in rough environment thalli appears delicate while under relatively calm environment they may grow to large size (Graham \& Wilcox 2000). The present study also showed that the plants which grow on wave sheltered surface of rock e. g. specimens Hedavi I and Harihareshwar showed broadly ovate to orbicular shape whereas other specimens which grow on wave exposed rock showed long linear to lanceolate shaped thalli. This was also interpreted by Hus (1902) and Gabriela (1990). Furthermore, the wave exposed plants showed thinner thalli as compared to wave sheltered plants. Thus, it can be inferred that the blade thickness is also affected by the water motion.
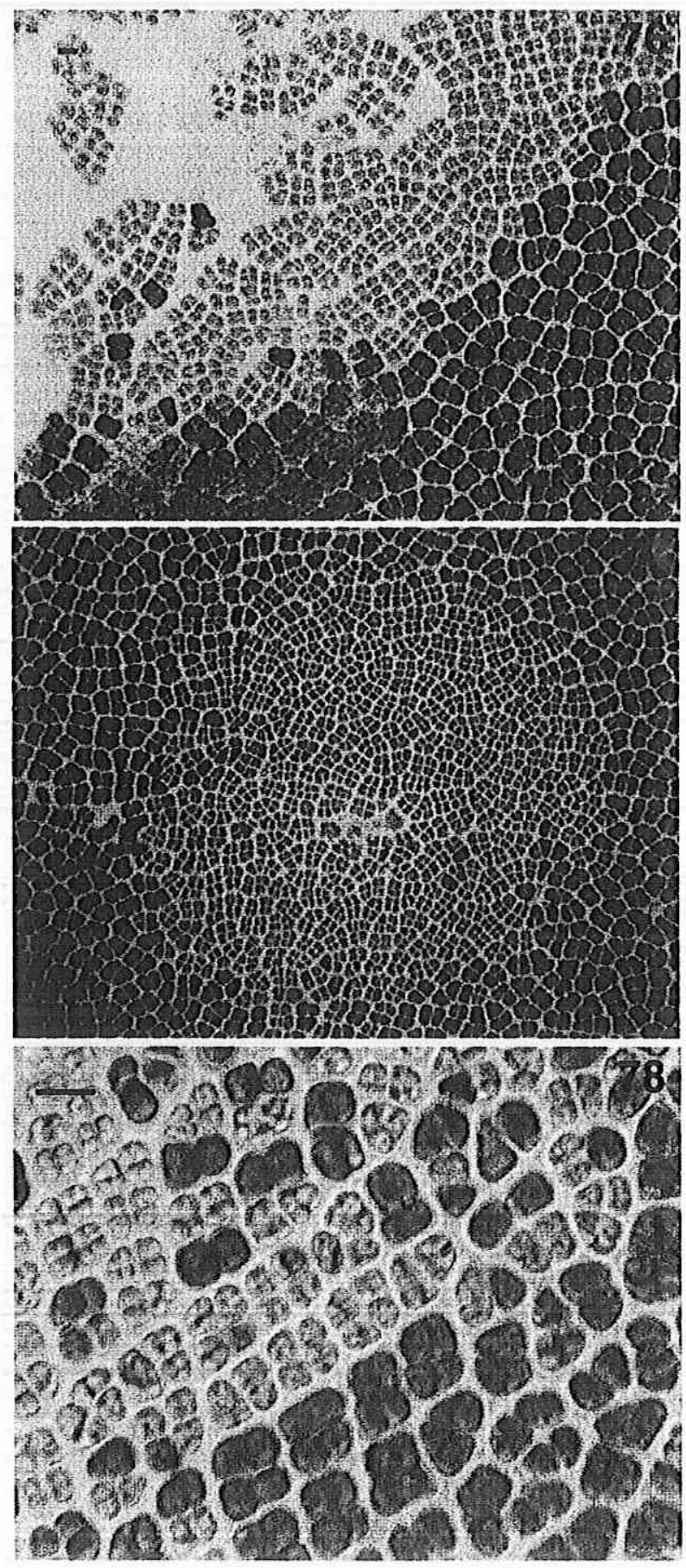

FIGURES 76-78. Surface view showing distribution of reproductive cells. Scale bar $=10 \mu \mathrm{m}$. 76. Distribution in strips. 77. Distribution in mixed. 78. Distribution in patches. 


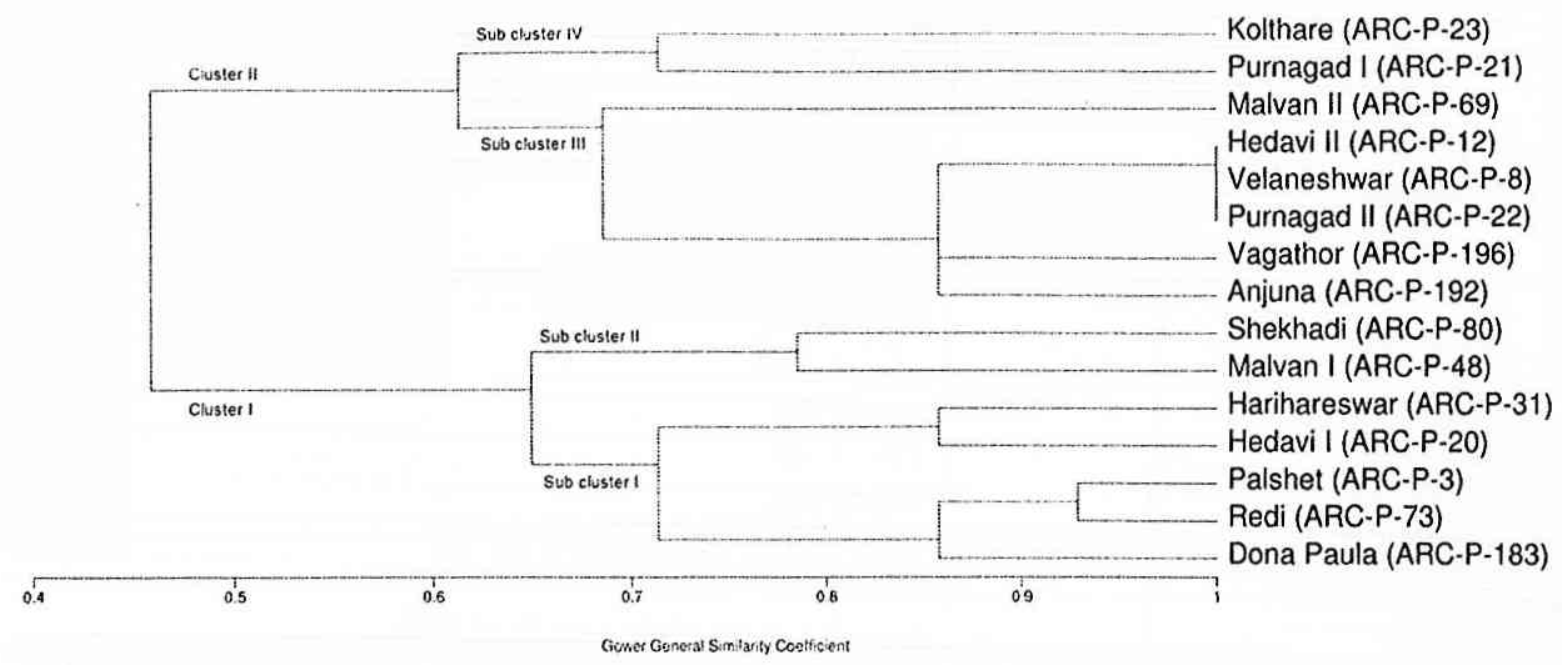

FIGURE 79. UPGMA phenogram based on the 11 morphological characters generated by Gower's general similarity coefficient.

\section{Morphological characterization}

In 1984, Krishnamurthy \& Baluswami compared the Indian specimen of $P$. vietnamensis with the type specimen described by Tanaka \& Ho (1962). In their study, the Indian specimen was found to be smaller and thicker. Since then, no detailed study was reported describing the morphological variation of $P$. vietnamensis from other regions of Indian waters. The present study showed high level of morphological plasticity in $P$. vietnamensis along the Konkan coast. The specimens described in the present study mainly differs from the type specimen in size and shape of the plant habitat, colour of the plant, thickness of the thallus, thickness of the mucilage, dimension and shape of the vegetative cells. Although several morphological characters showed variation in $P$. vietnamensis, some of the characters seem to be more or less constant for e.g. structure of the plant, sexuality, base of the plant, presence of spines, shape of the chromatophore, number \& formulae of spermatia and zygotospores. Most of the previous reports showed the occurrence of alga in the upper littoral zone. However, in the present study it was found to grow on entire intertidal region and this may be a possible reason for high morphological variation among the taxa.

\section{Molecular characterization}

The molecular analysis confirmed the identity of specimens as P. vietnamensis. The potential of coxl gene for biodiversity assessment of red algae has already been proved (Saunders 2005, Robba et al. 2006, Broadie et al. 2008, Sherwood et al. 2010, Kucera \& Saunders 2012, Milstein et al. 2012, Mols-Mortensen et al. 2012). The present analysis showed 0-1 bp intraspecific variation in Indian and Brazilian specimens which corroborated with the results for intraspecific variation range obtained for Pyropia by Milstein et al. (2012). However, question remains for the high variation in sequences of these specimens with Hawaiian specimen of $P$. vietnamensis (HQ422669) which showed closer relation to $P$. acanthophora clade. Furthermore, the morphological variations between Indian $P$. vietnamensis was not substantiated through molecular analysis wherein $\operatorname{coxl}$ gene sequences showed very low intraspecific variation. In conclusion, this study revealed that the variations in morphological characters in P. vietnamensis are mainly governed by environmental factors. However, to prove the genetic basis of this plasticity it needs further detailed study. Despite of similar environmental conditions and rock types Pyropia was missing from certain sites visited for collections. All these locations showed oil spills around the shore due to shipping base and their activities. In addition to this, the shore was also found to be marshy. These may be the possible reasons for absence of Pyropia from these sites. However, further detailed investigation with respect to nutrient availability, rock analysis and physicochemical parameters has to be carried out. The present study provides a beginning to a clearly required detailed study of the morphology, ecology and genetic diversity showed by Pyropia species from Indian waters. 


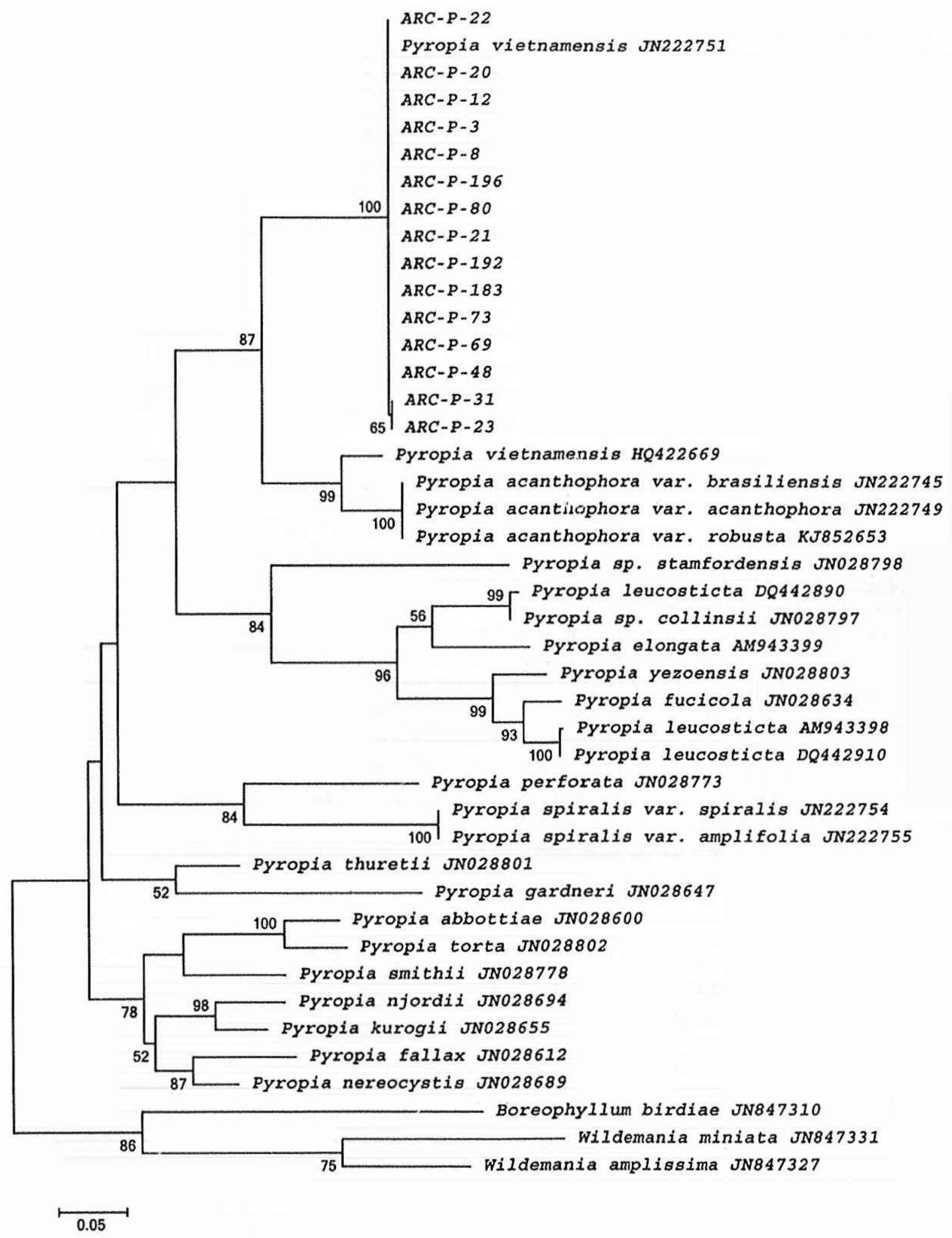

FIGURE 80. Phylogenetic tree based on $\operatorname{cox} l$ sequence data reconstructed using Maximum likelihood. Values at nodes represent bootstrap proportion (>50\%). 


\section{Acknowledgement}

We are thankful to NFBSFARA (National fund for Basic, Strategic and Frontier Application Research in Agriculture), ICAR, India for providing funds under the project No. NFBSFARA/CA-3002/2012-13. We also thank Kiran More and Nitesh Marchande for their assistance in the field collections and laboratory experiments.

\section{References}

Anilkumar, C. \& Rao P.S.N. (2005) A new species of Porphyra (Rhodophyta, Bangiales) from the Malvan coast of Maharashtra (India). Feddes Repertorium 116: 222-225. http://dx.doi.org/10.1002/fedr.200411069

Bhatia, S., Sharma, K., Namdeo, A.G., Chaugule, B.B., Kavale, M. \& Nanda, S. (2010) Broad- spectrum sun- protective action of Porphyra -334 derived from Porphyra vietnamensis. Pharmacognosy Research 2: 45-49. http://dx.doi.org/10.4103/0974-8490.60578

Bhatia, S., Sharma, A., Sharma, K., Kavale, M., Chaugule, B.B., Dhalwal, K., Namdeo, A.G. \& Mahadik, K.R. (2010) Novel algal polysaccharides from marine source: Porphyran. Pharmacognocy Reviews 2: 271-276.

Boergesen, F. (1937) Contribution to a South Indian Marine Algal Flora-II. Journal of the Indian Botanical Society 16: 311-357.

Brodie, J., Mols-Mortensen, A., Ramirez, M.E., Russell, S. \& Rinkel, B. (2008) Making the links: towards a global taxonomy for the red algal genus Porphyra (Bangiales, Rhodophyta). Journal of Applied Phycology 20: 939-949. http://dx.doi.org/10.1007/s10811-008-9315-7

Deodhar, H. D. (1987) The biology of marine algae of Bombay. Ph. D. Thesis. University of Pune, Pune. 200 pp.

Dhargalkar, V.K., Agadi, V.V \& Untawale, A.G. (1981) Occurrence of Porphyra vietnamensis (Bangiales, Rhodophyta) along the Goa coast. Mahasagar-Bulletin of the National Institute of Oceanography 14: 75-77.

Everitt, B. (1980) Cluster Analysis. 2nd Edition. Gower Publishing Co., Hampshire, 136 pp.

Felsenstein, J. (1985) Confidence limits on phylogenies: an approach using bootstrap. Evolution 39: 783-791. http://dx.doi.org/10.2307/2408678

Gabriela, H. (1990) Phenotypic plasticity in the red alga Porphyra abbottae: Environmental factors influencing light harvesting ability. $\mathrm{Ph}$. D. thesis. University of Washington, USA. $169 \mathrm{pp}$.

Graham, L.E. \& Wilcox, L.W. (2000) Algae. Prentice Hall, University of Michigan, Michigan. 640 pp.

Hus, H.T.A. (1902) An account of the species of Porphyra found on the Pacific coast of North America. Proceedings of the California Academy of sciences, third series. Botany 2: 173-238.

Kavale, M.G., Kazi, M.A. \& Sreenadhan, N. (2014) Pyropia acanthophora var. robusta var. nov. (Bangiales, Rhodophyta) from Goa, India. Indian Journal of Marine Sciences. (Accepted).

Kavale, M.G. \& Chaugule, B.B. (2013) Nutritional analysis of Porphyra vietnamensis (Rhodophyta) from Panchanadi Coast, Maharashtra. Seaweed Research Utilization 35: 138-143.

Kavale, M.G., Chaugule, B.B., Savardekar, S.V. \& Gokhale, N.B. (2013) Genetic variability in Porphyra C. Ag. along the coast of Maharashtra. Indian Journal of Biotechnology 12: 277-280.

Kimura, M. (1980)A simple method for estimating evolutionary rates of base substitutions through comparative studies of nucleotide sequences. Journal of Molecular Evolution 16: 111-120. http://dx.doi.org/10.1007/BF01731581

Krishnamurthy, V. \& Baluswami, M. (1984) The species of Porphyra from the Indian Region. Seaweed Research Utilization 7: 31-38.

Kucera, H. \& Saunders, G.W. (2012) A survey of Bangiales (Rhodophyta) based on multiple molecular markers reveals cryptic diversity. Journal of Phycology 48: 869-882. http://dx.doi.org/10.1111/j.1529-8817.2012.01193.x

Kumari, P., Bijo, A.J., Mantri, V.A., Reddy, C.R.K. \& Jha, B. (2013) Fatty acid profiling of tropical marine macroalgae: An analysis from chemotaxonomic and nutritional perspectives. Phytochemistry 86: 44-56. http://dx.doi.org/10.1016/j.phytochem.2012.10.015

Lobban, C.S., Harrison, P.J. \& Duncan, M.J. (1985) The physiological Ecology of Seaweeds. Cambridge University Press, New York, $242 \mathrm{pp}$.

Lobban, C.S. \& Harrison, P.J. (1994) Ecology and Physiology of seaweeds. Cambridge University Press. 136 pp. http://dx.doi.org/10.1017/CBO9780511626210

Milstein, D., Medeiros, A.S., Oliveira, E.C. \& Oliveira, M. C. (2012) Will a DNA barcoding approach be useful to identify Porphyra 
species (Bangiales, Rhodophyta)? Journal of Applied Phycology 24: 837-845.

http://dx.doi.org/10.1007/s10811-011-9702-3

Mols-Mortensen, A., Neefus, C.D., Nielsen, R., Gunnarsson, K., Egilsdóttir, S., Pedersen, P.M. \& Brodie, J. (2012) New insights into the biodiversity and generic relationships of foliose Bangiales (Rhodophyta) in Iceland and the Faroe Islands. European Journal of Phycology 47: 146-159. http://dx.doi.org/10.1080/09670262.2012.666678

Pereira, N., Kakode, J. \& Dhargalkar, V.K. (2005) Factors affecting the occurrence of Porphyra vietnamensis Tanaka \& Pham-Hoang Ho along the Goa coast. Current Science 88: 3-10.

Robba, L., Russell, S.J., Barker, G.L. \& Brodie, J. (2006) Assessing the use of the mitochondrial cox1 marker for use in DNA barcoding of red algae (Rhodophyta). American Journal of Botany 93: 1101-1108. ttp://dx.doi.org/10.3732/ajb.93.8.1101

Sahoo, D., Nivedita \& Debasish (2001) Seaweeds of Indian Coast. A. P. H. Publishing Corporation, New Delhi. 283 pp.

Sahoo, D., Baweja, P. \& Kushwah, N. (2006) Developmental studies in Porphyra vietnamensis: A high-temperature resistant species from the Indian coast. Journal of Applied Phycology 18: 279-286.

http://dx.doi.org/10.1007/s10811-006-9027-9

Saunders, G.W. (2005) Applying DNA barcoding to red macro-algae: a preliminary appraisal holds promise for future applications. Philosophical Transactions of the Royal Society B: Biological Sciences 360: 1879-1888. http://dx.doi.org/10.1098/rstb.2005.1719

Schwarz, G. (1978) Estimating the dimension of a model. The Annals of Statistics 6: 461-464. http://dx.doi.org/10.1214/aos/1176344136

Sherwood, A.R., Kurihara, A., Conklin, K.Y., Sauvage, T. \& Presting, G.G. (2010) The Hawaiian Rhodophyta Biodiversity Survey (20062010): a summary of principal findings. BMC Plant Biology 10: 258.

http://dx.doi.org/10.1186/1471-2229-10-258

Sreeramulu, T. (1952) On a Porphyra from Waltair coast. Science and Culture 18: 285-286.

Subba Rao, P.V., Mantri, V.A. \& Ganesan, K. (2007) Mineral Composition of edible seaweed Porphyra vietnamensis. Food chemistry 102: 215-218.

http://dx.doi.org/10.1016/j.foodchem.2006.05.009

Sutherland, J.E., Lindstrom, S.C., Nelson, W.A., Brodie, J., Lynch, M.D.J., Hwang, M.S., Choi, H-G., Miyata, M., Kikuchi, N., Oliveira, M.C., Farr, T., Neefus, C., Mols-Mortensen, A., Milstein, D. \& Müller, K.M. (2011) A new look at an ancient order: generic revision of the Bangiales (Rhodophyta). Journal of Phycology 47: 1131-1151.

http://dx.doi.org/10.1111/j.1529-8817.2011.01052.x

Tamura, K., Stecher, G., Peterson, D., Filipski, A. \& Kumar, S. (2013) MEGA6: Molecular Evolutionary Genetics Analysis Version 6.0. Molecular Biology and Evolution 30(12): 2725-2729. http://dx.doi.org/10.1093/molbev/mst197

Tanaka, T. \& Ho P-H. (1962) Notes on some Marine Algae from Viet-Nam-I. Memoirs of Faculty of Fisheries Kagoshima University Vol.11 (1).

Tavaré, S. (1986) Some probabilistic and statistical problems in the analysis of DNA sequences. In: some mathematical questions in biology-DNA sequence analysis, edited by R. M. Miura, American Mathematical Society, Providence (RI). 57-86 pp.

Umamaheswara Rao, U.M. \& Sreeramulu, T. (1963) Vertical zonation and seasonal variation in the growth of Porphyra on Visakhapatnam coast. Current Science 32: 173-174. 